\title{
Effect of chitosan and sodium alginate edible coatings on the postharvest quality of fresh-cut nectarines during storage
}

\author{
Valentina Chiabrando ${ }^{\star}$ and Giovanna Giacalone
}

DISAFA, Department of Agriculture, Forest and Food Science, Largo Braccini 2, Grugliasco (TO), Italy

Received 7 January 2015 - Accepted 12 October 2015

\begin{abstract}
Introduction. The use of edible coatings could be a new technological alternative to maintain fruit quality during cold storage. The objective of this work was to determine the effects of different coatings, alone or in conjunction, on the quality of fresh-cut nectarines during storage. Materials and methods. Nectarines (Prunus persica L.) cv. Big Top were studied under three different coatings: $2 \%$ acid-soluble chitosan, $1.5 \%$ sodium alginate, and a solution with $3 \%$ chitosan and $2 \%$ sodium alginate. Slices were then sealed in polyethylene plastic bags and stored at $4{ }^{\circ} \mathrm{C}$ and $95 \%$ RH for 9 days. Titratable acidity, soluble solids content, firmness, weight loss, color, browning potential and polyphenol oxidase activity were determined. Yeasts and molds were also monitored. Results and discussion. Nectarine firmness was maintained equally in all analyzed groups. The color parameter $\mathrm{L}^{*}$ showed a tendency to decrease with the increasing length of storage, with lower values in alginate- and alginate + chitosan-coated fruits. The chitosan coating decreased the metabolism activity of fruit during the cold storage without significant changes in the fruit quality (lightness and total soluble solid content). The chitosan coating also controlled the growth of microorganisms. Conclusion. The chitosan coating appears to be a promising preservation alternative and an effective method to improve the quality and shelf life of fresh-cut nectarines in marketing conditions.
\end{abstract}

Keywords: Italy / nectarine / Prunus persica / fruit coating / fresh-cut fruit / postharvest storage / shelf life

Résumé - Effet du chitosane et de l'alginate de sodium comme enrobages comestibles sur la qualité post-récolte des nectarines fraîches coupées en conservation. Introduction. L'utilisation d'un enrobage comestible pourrait être une nouvelle solution technologique pour maintenir la qualité des fruits découpés conservés au froid. L'objectif de ce travail était de déterminer les effets de différents enrobages, seuls ou associés, sur la qualité des nectarines fraîches coupées en conservation. Matériel et méthodes. La variété de nectarines (Prunus persica L.) 'Big Top' a été soumises à trois traitements d'enrobage différents : le chitosane à $2 \%$ soluble dans l'acide, l'alginate de sodium à 1,5\%, et une solution combinant le chitosane à $3 \%$ et l'alginate de sodium à $2 \%$. Les tranches de nectarine ont ensuite été scellées dans des sacs plastiques en polyéthylène et conservées à $4{ }^{\circ} \mathrm{C}$ et $95 \%$ d'humidité relative pendant 9 jours. L'acidité titrable, la teneur en composés solubles, la fermeté, la perte de poids, la couleur, le potentiel de brunissement et l'activité polyphénol oxydase ont été mesurés. Le développement de levures et moisissures a également été surveillé. Résultats et discussion. La fermeté des fruits s'est maintenue égale dans tous les traitements analysés. Le paramètre $\mathrm{L}^{*}$ de couleur a eu tendance à diminuer au cours de la conservation, avec des valeurs plus faibles pour les enrobages alginate seul et la combinaison [chitosane + alginate]. L'enrobage au chitosane a diminué l'activité du métabolisme des fruits pendant le stockage au froid sans changer de façon significative la qualité des fruits (vivacité du ton et contenu en composés solubles totaux). Le traitement au chitosan a également permis de contrôler la croissance des micro-organismes. Conclusion. L'enrobage au chitosane semble être une solution de conservation prometteuse et une méthode efficace pour maintenir la qualité et la durée de vie des nectarines conservées dans les conditions de mise en marché.

Mots clés : Italie / nectarine / Prunus persica enrobage / fruits frais coupés / stockage après récolte / aptitude à la conservation

\footnotetext{
^ Corresponding author: valentina.chiabrando@unito.it
} 


\section{Introduction}

Edible coatings protect food products from mechanical, physical, chemical and microbial damage, and could be a new technological alternative to maintain fruit quality during cold storage [1]. Coatings on products create a semi-permeable barrier to external elements that can reduce moisture loss, solute migration, respiration and oxidative reactions and retard the natural physiological ripening process [2]. However, choosing the appropriate coating formulation definitely affects the effectiveness of edible films and coatings. A range of polymers can be used in the edible coating formulation. Chitosan coating has been successfully used to sustain thequality in peach and nectarine fruits $[3,4]$. Moreover, chitosan shows antifungal activity and antimicrobial properties during storage $[5,6]$. Sodium alginate is a hydrophilic biopolymer that has a coating function because of its unique colloidal properties, which include its use for thickening, suspension forming, gel forming and emulsion stabilizing $[7,8]$. Sodium alginate films have been successfully used in apple and peach [9-11]. Maftoonazad et al. (2008) [9] found that the shelf life of pieces of peach could be extended using sodium alginate and methyl cellulose coatings. Different studies $[12,13]$ focused on edible coatings on whole fruit of nectarine and peach. Pizato et al. (2013) [14] applied different coatings to cubes of peach.

Fresh-cut fruit is one of the most promising areas where edible coatings can be applied because this technique can compensate for the damage inflicted to fruit integrity in the course of minimal fruit processing (washing, sorting, trimming, peeling and slicing), and thus control deterioration and extend the market life of the products. New strategies and technologies to maintain quality and extend shelf life are required in order to make the marketing of these products viable. The development of antimicrobial edible coatings as a cost-effective means to improve the shelf life of fresh-cut fruit has been investigated and its potential demonstrated $[15,16]$. The objective of the present study was to evaluate different coating formulations consisting of chitosan and sodium alginate in order to assess their effects on the physical, chemical and hygienic parameters of fresh-cut nectarines during 9 days of refrigerated storage.

\section{Materials and methods}

\subsection{Plant material}

Nectarines (Prunus persica (L.) Batsch., 'Big Top') were harvested at commercial maturity, and stored for one day $\left(4{ }^{\circ} \mathrm{C}\right.$ and $95 \%$ relative humidity, $\mathrm{RH}$ ) before processing. The fruits were cut into 15 -mm-thick slices.

\subsection{Preparation of coating solutions}

Three different coatings were prepared. A $2 \%(\mathrm{w} / \mathrm{v})$ acidsoluble chitosan (Sigma-Aldrich Co., Steinhein, Germany) coating solution was prepared by dissolving chitosan in $1 \%$ aqueous acetic acid with $50 \%$ glycerol and $0.15 \%$ Tween $20(\mathrm{w} / \mathrm{v})$ in accordance with Duan et al. [17]. The coating was homogenized for $90 \mathrm{~s}$ and then stored overnight at room temperature. Slices were immersed in the chitosan solution for $2 \mathrm{~min}$ and air-dried at room temperature for $30 \mathrm{~min}$.

A $1.5 \%(\mathrm{w} / \mathrm{v})$ sodium alginate (Sigma-Aldrich Co., Steinhein, Germany) solution was prepared by dissolving the sodium alginate powder in distilled water upon stirring at $70{ }^{\circ} \mathrm{C}$ for $2 \mathrm{~h}$. Then, the solution was cooled to $25^{\circ} \mathrm{C}$ in accordance with Poverenov et al. [18]. Slices were immersed in the alginate solution for $2 \mathrm{~min}$ and then immersed in 5\% aqueous solution of $\mathrm{CaCl}_{2}$ for $2 \mathrm{~min}$ (Sigma-Aldrich Co., Steinhein, Germany) to perform gelation of alginate molecules by crosslinking. The samples were air-dried at room temperature for $30 \mathrm{~min}$.

A $1.5 \%(\mathrm{w} / \mathrm{v})$ chitosan and $1 \%(\mathrm{w} / \mathrm{v})$ sodium alginate coating solution was prepared by mixing $3 \%$ chitosan solution and $2 \%$ sodium alginate solution at a $1: 1$ ratio with $25 \%$ glycerol and $0.15 \%$ Tween 20 (w/v) in accordance with Duan et al. [17]. Slices were immersed in the chitosan + sodium alginate solution for $2 \mathrm{~min}$ and air-dried at room temperature for $30 \mathrm{~min}$.

A sample washed in water was used as control. Then, nectarine slices were randomly selected and packaged in polyethylene plastic bags $(20 \mathrm{~cm} \times 30 \mathrm{~cm}$ size and $397 \mu \mathrm{m}$ thickness) with $50 \mathrm{~cm}^{3} \mathrm{O}_{2} \mathrm{~m}^{-2} \mathrm{bar}^{-1} \mathrm{day}^{-1}$ and a $15 \mathrm{~g} \mathrm{~m}^{-2} \mathrm{bar}^{-1}$ day $^{-1}$ water vapor transmission rate (Sealed, Italy). The packages were completely sealed (UNIMEC Packaging Systems, Italy) and then were stored at $4{ }^{\circ} \mathrm{C}$ and $95 \%$ $\mathrm{RH}$ in darkness for 9 days.

\subsection{Weight loss}

Weight loss was determined by weighing the packages at the start of the experiment (time 0 ) and at days $0,2,6,7$ and 9 during storage. Values are reported as a percent of weight loss per initial nectarine package weight.

\subsection{Atmosphere composition}

The concentrations of oxygen and carbon dioxide inside the packages were monitored at days 2, 6, 7 and 9 during storage by sampling $(0.5 \mathrm{~mL})$ the headspace using a CANAL 121 (Vizag, Gas Analysis, France). A syringe was inserted into the package through a rubber seal placed on the film. Gases were analyzed with an electrochemical sensor for $\mathrm{O}_{2}$ level and an infrared sensor for $\mathrm{CO}_{2}$ level. The instrument was calibrated in air. Results were expressed as $\mathrm{kPa}$ of $\mathrm{O}_{2}$ and $\mathrm{CO}_{2}$ inside the packs.

\subsection{Fruit quality evaluation}

Physicochemical quality attributes of nectarine slices were measured before cold storage (time 0 ) and then after 9 days of storage.

Total soluble solid content, $\mathrm{pH}$ and titratable acidity were measured using juice extracted from 5 slice samples blended at high speed in a homogenizer. Three replications were used for each coating treatment. The soluble solid concentration was 
determined by a digital refractometer (Atago refractometer, model PR-32) and the results expressed as ${ }^{\circ}$ Brix. Titratable acidity and $\mathrm{pH}$ were measured by titrating 1:10 diluted juice, using $0.1 \mathrm{~N} \mathrm{NaOH}$ and an automatic titrator (Compact 44-00, Crison).

Textural measurements were carried out before cold storage (time 0 ) and after 3, 7, 8 and 9 days of storage. Nectarines were randomly selected for analysis and 15 replicates (slices) were analyzed for each coating treatment. Before the analysis, samples were cooled to room temperature $\left(20{ }^{\circ} \mathrm{C}\right)$ for $3 \mathrm{~h}$, because most fruits and vegetables show decreasing firmness with increasing temperature [18]. Fruit firmness was determined by penetration using a TA.XT2 $\mathrm{i}^{\circledR}$ Texture Analyzer (Stable Micro Systems, UK). Measurements were performed in the equatorial part of the slice, at a crosshead speed of $3 \mathrm{~mm} / \mathrm{s}$ and with a 3-mm-diameter punch [19]. A $5-\mathrm{kg}$ load cell was used for firmness determination and the probe was programmed to penetrate $3 \mathrm{~mm}$ into the slice. The maximum penetration force $(\mathrm{N})$, which is related to the firmness of the samples, was the parameter selected for further statistical analysis.

The color of coated nectarine slices was measured at days $0,3,7,8$ and 9 of storage individually in each slice (15 replicates for each treatment). Surface color was analyzed with a tri-stimulus CR-400 Chroma Meter (Konica Minolta Sensing) with the illumining D75 and an observation angle of $10^{\circ}$ calibrated with a standard white plate $(\mathrm{Y}=94.00, \mathrm{x}=$ $0.3158, y=0.3322$ ). Readings of $L^{*}$ (lightness), $b^{*}$ (yellow chromaticity) and $\mathrm{a}^{*}$ (green chromaticity) coordinates were recorded. Also, $\mathrm{h}^{*}$ (hue or angle of color, $0^{\circ}=$ purple-red and $90^{\circ}=$ yellow) values were measured. The reported values are the means \pm SD of 15 measurements.

\subsection{Browning potential}

Browning potential was determined according to the method of Arias et al. [21] at days 4 and 7 of storage. The extract was obtained as follows: nectarine slices $(25 \mathrm{~g})$ from each treatment were homogenized for $2 \mathrm{~min}$ at 13,500 rpm with an Ultra-Turrax T25 (IKAs WERKE, Germany), the homogenates were centrifuged (Centrifuge AVANTITM J-25, Beckman Instruments Inc., Fullerton, CA, USA) at 4,000 rpm for $10 \mathrm{~min}$ and the supernatant was filtered through Whatman 4 filter paper (Whatman Intl., UK). The absorbance of the clear juice was then measured spectrophotometrically (Hitachi, U-5100, Japan) at $440 \mathrm{~nm}$ to determine the browning potential (BP). This measurement was replicated three times for each coating treatment.

\subsection{Polyphenol oxidase activity (PPO)}

Determination of the PPO activity was performed at days 4 and 7 of cold storage at $4{ }^{\circ} \mathrm{C}$.

\subsubsection{Enzyme extraction}

A portion of $50 \mathrm{~g}$ nectarine slices was mixed with a buffer solution (1:1) at pH 6.5 containing $1 \mathrm{M} \mathrm{NaCl}$ (Sigma-Aldrich
Chemie, Steinheim, Germany) and 5\% polyvinylpolypyrrolidone (Sigma-Aldrich Chemie, Steinheim, Germany). The mixture was blended and homogenized using an Ultra-Turrax T25 (IKAs WERKE, Germany). The homogenate was centrifuged at $12,000 \mathrm{rpm}$ for $30 \mathrm{~min}$ at $4{ }^{\circ} \mathrm{C}$ (Centrifuge AVANTITM J-25, Beckman Instruments Inc., U.S.A.). The supernatant was collected and filtered through Whatman 1 paper (Whatman Intl., U.K.), and the resulting solution constituted the enzymatic extract, which was used for enzyme activity determination.

\subsubsection{PPO activity measurement}

Polyphenoloxidase activity was determined according to the method of Soliva-Fortuny et al. [22] and Kołodziejczyk et al. [23]. Enzyme activity was assayed spectrophotometrically by adding $3 \mathrm{~mL}$ of $0.05 \mathrm{M}$ catechol (Sigma-Aldrich Chemie, Steinheim, Germany) and $75 \mu \mathrm{L}$ of extract to a $4.5-\mathrm{mL}$ quartz cuvette of $1 \mathrm{~cm}$ path length. The changes in absorbance at $400 \mathrm{~nm}$ were recorded every $5 \mathrm{~s}$ up to $3 \mathrm{~min}$ from the time the enzyme extract was added using a Beckman $\mathrm{Du}^{\circledR} 530$ spectrophotometer. One unit of PPO activity was defined as a change in absorbance of $0.001 \mathrm{~min}^{-1} \mathrm{~mL}^{-1}$ of enzymatic extract immediately after extract addition. The initial reaction rate was estimated from the linear portion of the plotted curve. All determinations were performed in triplicate.

\subsection{Microbiological analysis}

To evaluate the microbiological efficiency of the coatings, microbiological analyses of yeasts and molds were carried out at the end of the storage period, according to the methodology described by the Compendium of Methods for the Microbiological Examination of Foods [24]. Yeast and mold counts were performed using chloramphenicol glucose agar (CGA) [25]. All the plates were incubated at room temperature for 3-5 days. Three replicates were analyzed and microbiological counts were expressed as colony-forming units (CFU) $\mathrm{g}^{-1}$ sample.

\subsection{Statistical analysis}

Data were analyzed by analysis of variance, using statistical procedures of STATISTICA ver. 6.0 (StatSoft Inc., Tulsa, OK, USA). The source of variance is coating treatments. Tukey's HSP test (honest significant differences) was used to determine significant differences among treatment means. Mean values were considered significantly different at $P \leqslant$ 0.05 .

\section{Results and discussion}

\subsection{Atmosphere composition}

The $\mathrm{O}_{2}$ content in all fruit packs decreased as a result of fresh-cut fruit respiration and transpiration. The dynamics 


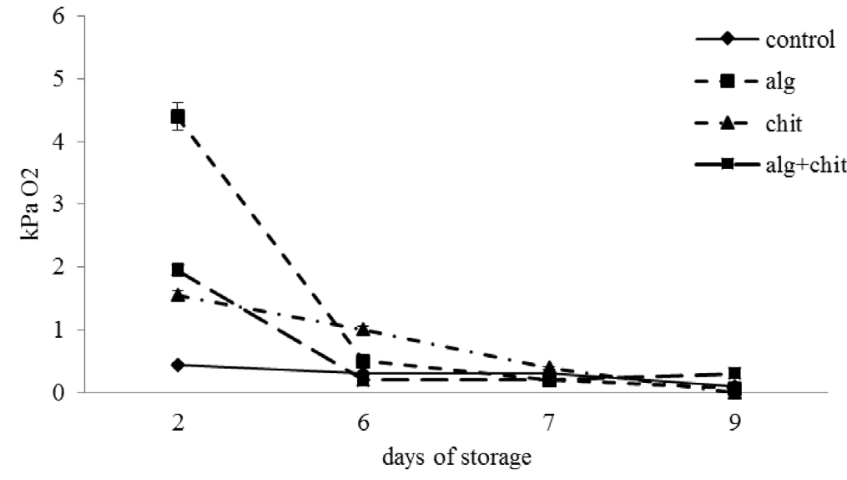

Figure 1. Changes in $\mathrm{O}_{2}$ levels of fresh-cut nectarine dipped in different coating solutions and stored for 9 days at $4{ }^{\circ} \mathrm{C}$. Values are the means \pm SD of 3 determinations. Control $=$ no treatment, alg $=1.5 \%$ sodium alginate, chit $=2 \%$ chitosan, alg + chit $=3 \%$ chitosan solution and $2 \%$ sodium alginate.



Figure 2. Changes in $\mathrm{CO}_{2}$ levels of fresh-cut nectarine dipped in different coating solutions and stored for 9 days at $4{ }^{\circ} \mathrm{C}$. Values are the means \pm SD of 3 determinations. Control $=$ no treatment, $\operatorname{alg}=1.5 \%$ sodium alginate, chit $=2 \%$ chitosan, alg + chit $=3 \%$ chitosan solution and $2 \%$ sodium alginate.

of oxygen concentration is shown in figure 1 . The highest decrease in $\mathrm{O}_{2}$ content during the 9 storage days was observed in alginate sample packs, and the lowest in alginate + chitosancoated samples.

The changes in attributes of packaged nectarines may be related to the changes in $\mathrm{O}_{2}$ and $\mathrm{CO}_{2}$ levels in the package due to the respiration of the tissue (figures 1,2 ). Nectarine slices passively modified the internal atmosphere; $\mathrm{CO}_{2}$ partial pressure gradually increased, while $\mathrm{O}_{2}$ levels progressively decreased. Gorny [26] concluded that a reduction of $\mathrm{O}_{2}$ levels to near $0 \mathrm{kPa}$ retains firmness, extends shelf life, and is required to inhibit polyphenoloxidase (PPO) in many freshcut fruit products. Other studies reported significant changes in fresh-cut fruits after processing, in particular due to the effects of wounding caused by cutting, with a respiratory rate of about twice to three times higher than that reported for whole fruit $[27,28]$.

The atmosphere generated in the packs was somewhat extreme in that the $\mathrm{CO}_{2}$ levels were high $(>20 \%$ at the end of storage), although with the low $\mathrm{O}_{2}(<1 \%)$ levels present the anaerobic limit was avoided (since no alcohol off-flavor was detected).



Figure 3. Weight loss (\%) of fresh-cut nectarine dipped in different coating solutions and stored for 9 days at $4{ }^{\circ} \mathrm{C}$. Values are the means \pm $\mathrm{SD}$ of 3 determinations. Control $=$ no treatment, $\mathrm{alg}=1.5 \%$ sodium alginate, chit $=2 \%$ chitosan, alg + chit $=3 \%$ chitosan solution and $2 \%$ sodium alginate.

\subsection{Weight loss}

The observed weight loss of nectarine slices was about $0.6-1.1 \%$ during the 9 days of storage (figure 3). Among samples, significantly higher weight loss values were obtained in alginate + chitosan samples at the end of the storage period. Differences in the ability to reduce weight loss are attributed to the different water vapor permeability of the polysaccharides used in the formulation of the edible coating [5].

The addition of glycerol as a plasticizer in the coating gave good results in terms of reducing sample weight loss, according to previous research on strawberry [29] and apple [30]. In this research, the alginate coating provided a better water barrier property than the other coatings, and thus reduced the weight loss of coated slices during storage.

\subsection{Quality evaluations}

The physicochemical properties of fresh-cut nectarines during the postharvest storage period are presented in table $I$ and figures 4-6. The total soluble solid content of sample slices before coating treatments (day 0 ) was $10.8^{\circ}$ Brix. At the end of the storage period the chitosan-coated slices and control nectarines showed significantly greater values, in accordance with the research of Chien et al. [15] on mango fruits. Alginate- and alginate + chitosan-coated slices showed the lowest values. The reducing sugar content in these samples suggested that in these treatments the slices synthesized reducing sugars at a slower rate than the control and other treatments, as observed before for banana and mango coated with polysaccharide-based coatings [31].

A decrease in total acidity is typical during postharvest storage and has been attributed to the use of organic acids as substrates for the respiratory metabolism. Alginate coating delays the utilization of organic acids [32]. The results confirmed this after 9 days of storage. In fact, at the end of the storage period, the alginate samples showed significant higher titratable acidity values compared with the other two coatings. 
Table I. Effect of different coatings on quality parameters of fresh-cut nectarine dipped in different coating solutions and stored for 9 days at $4{ }^{\circ} \mathrm{C}$. Control $=$ no treatment, $\mathrm{Alg}=1.5 \%$ sodium alginate, Chit $=2 \%$ chitosan, $\mathrm{Alg}+\mathrm{Chit}=3 \%$ chitosan solution and $2 \%$ sodium alginate . Different letters in the same storage time indicate significant differences $(P \leqslant 0.05)$.

\begin{tabular}{lccccc}
\hline & & \multicolumn{4}{c}{ Days of storage } \\
\cline { 3 - 6 } Quality parameters & Treatments & 0 & 4 & 9 & 7 \\
\hline Total soluble solids $\left({ }^{\circ}\right.$ Brix) & Control & 10.8 & & $11.2 \mathrm{a}$ & \\
& Alg & 10.8 & & $10.5 \mathrm{ab}$ & \\
& Chit & 10.8 & & $11.2 \mathrm{a}$ & \\
& Alg+Chit & 10.8 & & $10.2 \mathrm{~b}$ & \\
\hline Titratable acidity $\left(\mathrm{meq} \mathrm{L}^{-1}\right)$ & Control & 75.72 & & $73.84 \mathrm{a}$ & \\
& Alg & 75.72 & & $75.06 \mathrm{a}$ & \\
& Chit & 75.72 & & $71.64 \mathrm{~b}$ & \\
& Alg+Chit & 75.72 & & $63.86 \mathrm{c}$ & \\
\hline pH & Control & 5.04 & & $4.61 \mathrm{~b}$ & \\
& Alg & 5.04 & & $4.55 \mathrm{~b}$ & \\
& Chit & 5.04 & & $5.01 \mathrm{a}$ & \\
& Alg+Chit & 5.04 & & $4.91 \mathrm{a}$ & \\
\hline Browning Potential $($ Abs $440 \mathrm{~nm})$ & Control & & $2.29 \mathrm{a}$ & & $1.60 \mathrm{a}$ \\
& Alg & & $0.77 \mathrm{c}$ & & $0.81 \mathrm{~b}$ \\
& Chit & & $1.49 \mathrm{~b}$ & & $1.57 \mathrm{a}$ \\
& Alg+Chit & & $1.09 \mathrm{c}$ & & $0.75 \mathrm{~b}$ \\
\hline Relative PPO activity $\left(\mathrm{cfu} \mathrm{g}{ }^{-1}\right)$ & Control & $0.0068 \mathrm{~b}$ & & $0.009 \mathrm{~b}$ \\
& Alg & & $0.0047 \mathrm{~b}$ & & $0.007 \mathrm{~b}$ \\
& Chit & & $0.0155 \mathrm{a}$ & & $0.013 \mathrm{a}$ \\
& Alg+Chit & & $0.0026 \mathrm{~b}$ & & $0.010 \mathrm{~b}$ \\
\hline & & &
\end{tabular}



Figure 4. Changes in $\mathrm{L}^{*}$ values of fresh-cut nectarine dipped in different coating solutions and stored for 9 days at $4{ }^{\circ} \mathrm{C}$. Values are the means \pm SD of 15 determinations. Control $=$ no treatment, $\operatorname{alg}=1.5 \%$ sodium alginate, chit $=2 \%$ chitosan, alg + chit $=3 \%$ chitosan solution and $2 \%$ sodium alginate.

The results of changes in the color of nectarine slices in terms of lightness and $\mathrm{h}$ values during storage (figures 4 , 5) showed a general decreasing trend. The chitosan coating slowed the decrease in luminosity of samples, which became significant with chitosan and alginate + chitosan coatings, that showed the lowest $\mathrm{L}^{*}$ values. Changes in the surface reflection properties when the fruit is coated can provoke this luminosity decrease. It is probable that the alginate film turned opaque during film formation at the final stage of drying, resulting

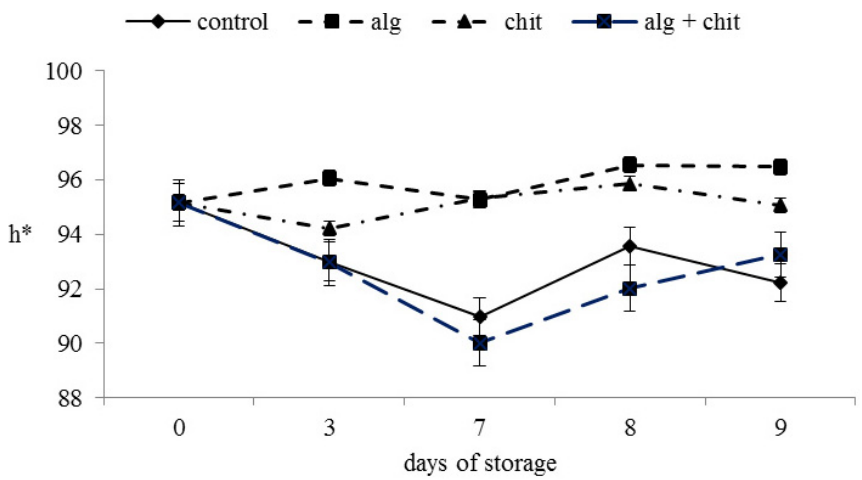

Figure 5. Changes in $h^{*}$ values of fresh-cut nectarine dipped in different coating solutions and stored for 9 days at $4{ }^{\circ} \mathrm{C}$. Values are the means \pm SD of 15 determinations. Control $=$ no treatment, $\operatorname{alg}=1.5 \%$ sodium alginate, chit $=2 \%$ chitosan, alg + chit $=3 \%$ chitosan solution and $2 \%$ sodium alginate.

in lower $\mathrm{L}^{*}$ values. $\mathrm{H}^{*}$ values remained quite stable during postharvest storage, in particular in alginate- and chitosancoated slices.

The firmness of sample slices before coating treatments (day 0) was $8.15 \mathrm{~N}$, which increased in the chitosan coating, increased and then decreased in alginate, decreased in control samples and remained quite stable in alginate + chitosancoated nectarines during storage (figure 6). The increased in texture values is in accordance with previous work on 


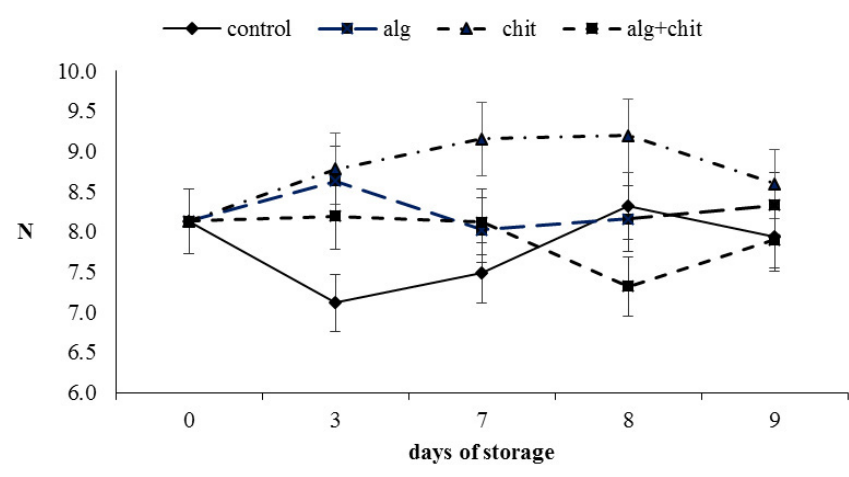

Figure 6. Changes in firmness $(\mathrm{N})$ values of fresh-cut nectarine dipped in different coating solutions and stored for 9 days at $4{ }^{\circ} \mathrm{C}$. Values are the means \pm SD of 15 determinations. Control $=$ no treatment, alg $=1.5 \%$ sodium alginate, chit $=2 \%$ chitosan, alg + chit $=$ $3 \%$ chitosan solution and $2 \%$ sodium alginate.

Table II. Effect of different coatings on microbiological parameters (yeasts and molds) of fresh-cut nectarine after 9 days of cold storage. Control $=$ no treatment, $\mathrm{Alg}=1.5 \%$ sodium alginate, Chit $=2 \%$ chitosan, $\mathrm{Alg}+\mathrm{Chit}=3 \%$ chitosan solution and $2 \%$ sodium alginate.

\begin{tabular}{lcc}
\hline Treatments & $\begin{array}{c}\text { Yeasts } \\
\left(\text { ufc g }^{-1}\right)\end{array}$ & $\begin{array}{c}\text { Molds } \\
\left(\text { ufc g }^{-1}\right)\end{array}$ \\
\hline Control & 1,100 & 75 \\
Alg & 6,500 & 160 \\
Chit & $<10$ & 55 \\
Alg+Chit & 5,200 & 620 \\
\hline
\end{tabular}

blueberries [20]. However, the difference among the edible coatings' sample firmness after 9 days of storage was not substantial.

Browning potential decreased or remained quite stable over the 9 days of storage, and control and chitosan-treated slices had higher browning potential compared with the other samples. After 9 days of storage, the lowest browning potential was observed in alginate-coated nectarine slices (table $I$ ).

The PPO activity of fresh-cut nectarines treated with edible coating solutions increased during storage (table I). The increase in PPO activity might be due to the activation of soluble tyrosinase forms existing in a latent state, which can be activated during storage by several factors [33]. In this study we noted that the PPO activity was different depending on the type of treatment used; in particular, after 9 days of storage the highest PPO activity was observed in chitosan- and chitosan + alginate-coated samples. Alginate coating is more effective at controlling PPO activity during storage.

\subsection{Microbiological analysis}

Microbial safety is one of the most important factors to be considered for the preservation of fruits during the postharvest period, in particular for fresh-cut fruit. The results on the microbiological quality of the different edible coating-treated nectarine slices at the end of the storage period (9 days) are presented in table II. Slices treated with the chitosan edible coating minimized the growth of yeasts and molds to values

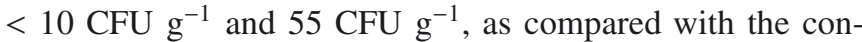
trol and the other coatings. The chitosan coating on freshcut nectarine effectively inhibited the growth of microorganisms during the postharvest period, in accordance with Chieg et al. [15] in mango, Hernandez-Munoz et al. [34] in strawberry and Gonzalez-Aguilar et al. [35] in papaya.

\section{Conclusion}

The different coatings studied showed different effects on the physical, chemical and hygienic parameters of fresh-cut nectarine during storage. The alginate coating showed lower values of firmness and lightness during storage and lower values of total soluble solid content at the end of storage. The chitosan coating decreased the metabolism activity of fruit during storage and showed lower weight loss, and higher values of lightness, firmness and total soluble solid content compared with the other treatments. Moreover, the chitosan coating controlled the growth of microorganisms. The chitosan coating appears to be a promising preservation alternative and an effective method to improve the quality and shelf life of nectarines in marketing conditions.

Future research will focus on the effects of these edible coatings on the sensory quality of fresh-cut nectarine during storage, to select the best for commercial purposes.

Acknowledgements. The authors thank Sealed Air for supplying samples of film and technical support.

\section{References}

[1] Campos C.A., Gerschenson L.N., Flores S.K., Development of edible films and coatings with antimicrobial activity, Food Bioproc. Technol. 4 (2011) 849-875.

[2] Vargas M., Pastor C., Chiralt A., McClements J., González Martínez C., Recent advances in edible coatings for fresh and minimally processed fruits, Crit. Rev. Food Sci. Nutrit. 48 (2008) 496-511.

[3] Chiabrando V., Giacalone G., Effect of different coatings in preventing deterioration and preserving the quality of fresh-cut nectarines (cv Big Top), J. Food 11 (2013) 285-292.

[4] Li H., Yu T., Effect of chitosan coating on incidence or brown rot, quality and physiological attributes for postharvest peach fruit, J. Sci. Food Agric. 81 (2001) 269-274.

[5] Chien P.J., Sheu F., Yang F.H., Effects of edible chitosan coating on quality and shelf life of sliced mango fruit, J. Food Eng. 78 (2007) 225-229.

[6] Devlieghere F., Vermeulen A., Debevere J., Chitosan, Antimicrobial activity, interactions with food components and applicability as a coating on fruit and vegetables, Food Microbiol. 21 (2009) 703-714.

[7] Acevedo C.A., López D.A., Tapia M.J., Enrione J., Skurtys O., Pedreschi F., Brown D.I., Creixell W., Osorio F., Using RGB image processing for designating an alginate edible film, Food Bioproc. Technol. 5 (2012) 1511-1520.

[8] Ferrari C.C., Sarantoulos C.I.G.L., Effect of osmotic dehydration and pectin edible coatings on quality and shelf life of freshcut melon, Food Bioproc. Technol. 6 (2013) 80-91. 
[9] Maftoonazad N., Ramaswamy H.S., Marcotte M., Shelflife extension of peaches through sodium alginate and methyl cellulose edible coatings, Int. J. Food Sci. Technol. 43 (2008) 951-957.

[10] Olivas G.I., Mattinson D.S., Barbosa Cánovas G.V., Alginate coatings for preservation of minimally processed Gala apples, Post. Biol. Technol. 45 (2007) 89-96.

[11] Rojas Grauü M.A., Tapia M.S., Rodríguez F.J., Carmona A., Martin Belloso O., Alginate and gellan-based edible coatings as carriers of antibrowning agents applied on fresh-cut Fuji apples, Food Hydrocol. 21 (2007) 118-127.

[12] Oliveira M.A., Cereda M.P., Pós-colheita de pêssegos Prunus persica $\mathrm{L}$. Bastsch revestidos com filmes a bvase de amido como alternativa à cera comercial. Ciênc. Tecnol. Aliment. 23 (2003) 28-33.

[13] Togrul H., Arslan N., Extending shelf-life of peach and pear by using $\mathrm{CMC}$ from sugar beet pulp cellulose as a hydrophilic polymer in emulsions. Food Hydrocolloid. 18 (2004) 215-226.

[14] Pizato S., Cortez-Vega W.R., Andreghetto De Souza J.T., Prentice-Hernandez C., Dellinghausen Borgen C., Effects of different edible coatings in physical, chemical and microbiological characteristics of minimally processed peaches Prunus persica 1. Batsch. J. Food Saf. 33 (2013) 30-39.

[15] Brasil I.M., Gomes C., Puerta-Gomez A., Castell-Perez M.E., Moreira R.G., Polysaccharide-based multilayered antimicrobial edible coating enhances quality of fresh-cut papaya. Food Sci. Technol. 1(2012) 39-45.

[16] Salvia-Trujillo L., Rojas-Graü M.A., Soliva-Fortuny R., MartínBelloso O., Use of antimicrobial nanoemulsions as edible coatings: Impact on safety and quality attributes of fresh-cut Fuji apples. Post. Biol. Technol. 105 (2015) 8-16.

[17] Duan J., Wu R., Strik B.C., Zhao Y., Effect of edible coatings on the quality of fresh blueberries (Duke and Elliott) under commercial storage conditions, Post. Biol. Technol. 59 (2011) 71-79.

[18] Poverenov E., Danino S., Horev B., Granit R., Vinokur Y., Rodov V., Layer-by-layer electrostatic deposition of edile coating on fresh-cut melon model: anticipated and unexpected effect of alginate-chitosan combination, Food Bioproc. Technol. 7 (2014) 1424-1432.

[19] Bourne M.C., Textural evaluation of horticultural crops, HortSci. 15 (1980) 5-56.

[20] Chiabrando V., Giacalone G., Rolle L., Mechanical behavior and quality traits of highbush blueberry during postharvest storage, J. Sci. Food Agric. 89 (2009) 989-992.

[21] Arias E., Gonzalez J., Lopez-Buesa P., Oria R., Optimization of processing of fresh-cut pear, J. Sci. Food Agric. 88 (2008) $1755-1763$.

[22] Soliva-Fortuny R.C., Grigelmo-Miguel N., Odrizola-Serrano I., Gorinstein S., Martin-Belloso O., Browning evaluation of ready-to-eat apples as affected by modified atmosphere packaging, J. Agric. Food Chem. 49 (2001) 3685-3690.

[23] Kołodziejczyk K., Milala J., Sójka M., Kosmala M., Markowski J., Polyphenol oxidase activity in selected apple cultivars. J. Fruit Ornamental Plant. Res. 18 (2010) 51-61.

[24] Vanderzant C., Splittstoesser D.F., Compendium of methods for the microbiological examination of foods (3rd ed.) American Public Health Association (APHA), Washington, 1992, pp. 1219.

[25] ISO 21527. International Organization for Standardization Publications. Microbiology of food and animal feeding stuffs. Horizontal method for the enumeration of yeasts and moulds. www.iso.org (2008).

[26] Gorny J.R.A., Summary of CA and MA requirements and recommendations for the storage of fresh-cut (minimally processed) fruits and vegetables, On: 7th Int. Controlled Atmosphere Res. Conference, Davis, CA, July 13-18, 1997, 5, 30-66.

[27] Lakakul R., Beaudry M.H.R.J., Modeling respiration of apple slices in modified-atmosphere packages, J. Food Sci. 64 (1999) 105-110.

[28] Soliva-Fortuny R.C., Lluch M.A., Quiles A., Grigelmo-Miguel N., Martín-Belloso O., Evaluation of textural properties and microstructure during storage of minimally processed apples, J. Food Sci. 68 (2003) 312-317.

[29] García M.A., Martino M.N., Zaritzky N.E., Starch-based coatings: effect on refrigerated strawberry (Fragaria ananassa) quality, J. Sci. Food Agric. 76 (1998) 411-420.

[30] Moldão M.M., Beirão da Costa S.M., Beirão da Costa M.L., The effects of edible coatings on postharvest quality of the "Bravo de Esmolfe" apple, Eur. Food Res. Technol. 217 (2003) 325-328.

[31] Kittur F.S., Saroja N., Haibibunnisa M.S., Tharanathan R.N., Polysaccharide-based composite coating formulations for shelflife extension of fresh banana and mango, Eur. Food Res. Technol. 213 (2001) 306-311.

[32] Yaman O., Bayoindirli L., Effects of an edible coating and cold storage on shelf-life and quality of cherries, Lebnsm -Wiss. Und. Technol. 35 (2002) 146-150.

[33] Kahn V., Latency properties of polyphenol oxidase in two avocado cultivars differing in their rate of browning. J. Food Sci. Agric. 28 (1977) 233-239.

[34] Hernandez-Munoz P., Almenar E., Ocio M.J., Gavara R., Effect of calcium dips and chitosan coatings on postharvest life of strawberries (Fragaria $\times$ ananassa), Post. Biol. Technol. 39 (2006) 247-253.

[35] Gonzalez-Aguilar G.A., Valenzuela-Soto E., Lizardi-Mendoza J., Goycoolea F., Martınez-Tellez M.A., Villegas-Ochoa M.A., Monroy-Garcia I.N., Ayala-Zavala J.F., Effect of chitosan coating in preventing deterioration and preserving the quality of fresh-cut papaya 'Maradol', J. Sci. Food Agric. 89 (2009) $15-23$. 